$\xi=1$ 国

\title{
First Time Reporting of Key Audit Matters (KAM) by Malaysian Auditors
}

\author{
Hashanah Ismail $^{*}$, Asna Abdullah Atqa ${ }^{2}$, Hamimah Hassan $^{3}$ \\ ${ }^{1,2,3}$ Faculty of Economics \& Management, Universiti Putra Malaysia, Malaysia \\ *Corresponding author E-mail: pengsenam@gmail.com; asnaatqa@upm.edu.my
}

\begin{abstract}
This paper reports on the early first cohort of Audit Reports issued by external auditors in response to the requirement of ISA 701, Communication of Key Audit Matters (KAM) in the Auditor's Report, which became effective for audits of financial statements on or after 15 December 2016. Based on 15 Audit Reports of financial statements for year ending 31 December 2016 available in early 2017, this paper reports that only one out of 15 had a disclaimer and no KAM reported for the audit as ISA 701 specifies that no KAM should be reported following a disclaimer. The other fourteen audit reports were all clean reports with the number of KAMs reported ranging from one to five. The highest most significant audit matter reported was revenue recognition and inventory valuation followed by asset impairments of both tangible and intangible assets. Justifications by auditors of matters considered most significant ranged from no additional information (it is most significant because it is material) to articulate explicit link with business model and industry specific factors thus compliance with disclosure of KAM may be compliance de jour rather than compliance de facto. Despite the additional requirement to disclose KAM, this study finds no evidence of audit delays. All KAMs disclosed are elaborations of and related to a client's significant accounting policies choice. From KAM disclosures, readers of audit reports now are informed of the audit risk areas where estimates were made and judgments prevailed challenging auditors to exercise greater skepticism. This preliminary finding provides pointers for greater research into the cost benefits and communicative value of KAM disclosure in the Audit Reports of Listed companies in Malaysia.
\end{abstract}

Keywords: Key Audit Matters; Professional Skepticism; Revenue Recognition; Asset Impairment

\section{Introduction}

The auditor's report accompanying the financial statements issued in a company's annual report gives assurance to users of financial statements as to whether the audited financial statements are free from material misstatements or not. Materiality is determined by the auditor based on the auditor's assessment using the audit risk model. The materiality threshold set will define the boundary of how much evidence is needed and how much work needs to be performed. Such assurance gives credibility to the audited financial statements and therefore deemed useful for decision making by users of financial statements. In Malaysia, the Malaysian Institute of Accountants (MIA) mandates that audits must be performed in accordance with approved auditing standards to ensure minimum quality of work performed. The audit process of assessing risk of material misstatements and the appropriate response to the risks identified makes auditing a critical rather than difficult process involving judgment and the exercise of professional skepticism (1). What happens in the entire audit process must be documented as required by the standard on Audit Working Papers. These papers are not accessible to the users of audit reports. What users get is only an audit report with the auditor concluding in the form of an opinion following a standardized template issued by MIA. This practice will now change when MIA issued ISA 701, Communication of Key Audit Matters (KAM) in the Auditors' Report whereby the auditors are now required to include a new additional paragraph in the audit report, issues deemed as of the greatest significance during the audit dis- cussed and reported to those in charge of governance. The auditors are now required to be transparent to intended users of the audit report on key or critical areas of the audit. ISA701 therefore creates a new reporting regime to external auditors whereby for the first time auditors must disclose in a separate paragraph of the audit report matters limited only to those identified as most significant to the audit and why and how auditors responded. The changes are expected to bring benefits not only to auditors but also to auditees and users of audited financial statements. Although the audit report is now providing a lot more information as directed by ISA 701, not much coverage has been given by the media despite the claims that the market wants auditors to be more transparent. Given this new reporting regime to be effective for periods ending on or after 15 December 2016 what were the first reported KAMs identified by Malaysian external auditors and why?

It is the objective of this paper to examine the nature and extent of KAMs in the early batch of the pioneering audit report cohort for year ended 31 December 2016 and whether selecting KAMs, presenting it without a boiler plate template and reporting the responses to the KAMs lengthened the audit process thereby jeopardizing the timeliness of audit reports. To date there is no published study on KAMs and its impact in Malaysia. We believe this is the first study. It is exploratory and paves the way for more research in the near future. The paper is organized as follows: the next section presents the literature review followed by the methodology of the study. Results and discussion of the results are then presented before the paper concludes. 


\section{Literature Review}

This section presents a brief literature review based on the directives and guidance from MIA, the sole regulatory body of the accounting profession in Malaysia, as well as empirical work published on KAM from countries which had adopted KAM reporting earlier than Malaysia. Studies of audit regulations have used Institutional theory to explain why regulators of professions need to introduce regulations to its members. Bealing, Dirsmith, and Fogarty (3) examined the early regulatory actions by the Security Exchange Commission (SEC) in US as dramaturgy of political exchange. Regulators try to justify their role and acquire legitimacy via mandating its members to comply with the regulations issued. Part of the conformity by MIA in turn to International Auditing Standards issued by the International Auditing Standards Board, London, is also a process of conformity or isomorphism to pressures from global capital markets for standardized regulatory practices across the globe. Such isomorphism is termed coercive isomorphism. Baker, Bédard, and Prat dit Hauret (4) also conclude that external audit has evolved to be what it is today through coercive isomorphism, driven largely by regulations as regulators of the auditing profession internationally sought to maintain and justify their legitimacy.

There are limited studies on the usefulness of KAM disclosures in the audit report. Cordos and Fülöp (5) used an ex-ante approach by examining responses which were comments received by IAASB at the stage when the proposed new standard was just an Exposure Draft. The comments were received from respondents in the European Union countries. Most respondents agree that disclosure of KAM will have a positive impact on the audit reporting process. Likewise an experiment on non-professional investors showed that if KAM were placed prominently in the audit report, respondents were more likely to use it to change their investment decisions compared to if they only received a standard audit report (6).

Ex-post studies of the benefits and usefulness of KAM however, have produced mixed results, not all of which support the usefulness expected. In France the reporting of Justification of Assessments or KAM appears to be more symbolic than informative thus negating the intended usefulness of such disclosures as envisaged by regulators (7). As posited by Institutional theory, compliance which is coercive isomorphism may result in compliance in form, that is compliance de jour rather than compliance de facto. Lennox, Schmidt, and Thompson (8) report that first time reporting of KAM in the UK does not make the audit report incrementally informative to investors. What information is disclosed in the expanded audit report has been factored in by investors based on risk related information in earlier announcements preceding the release of the audit report. Disclosures do capture reliably the uncertainty in accounting measurements but lack incremental information content. Investors have been informed earlier from other sources made available of these risks areas of misstatements. Reid, Carcello, Li, and Neal (9) report that audit quality has improved after the implementation of KAM disclosures in the audit report as evidenced by reduction of abnormal accruals reduced after KAM disclosures.

The informational value of KAM disclosures has also had an attention directing impact (10). Investors pay more attention to KAM related matters and less to remaining parts of the audit report. Hence KAM disclosures have made information search and acquisition more efficient. Also in a litigious environment KAM disclosures could reduce the probability of potential legal actions against auditors when misstatements are the same as those identified in KAMS (11).

In sum therefore, results of prior literature have yielded mixed findings. Studies using various methods and focusing on specific users of the new audit report incorporating KAM disclosures report that in some jurisdictions KAM disclosures have brought positive effects whilst in others there are no effects.

\section{Methodology}

Data for this study is based on the audit reports available for year ending 31 December 2016 to capture the early birds affected by the new standard, ISA 701, which became effective for audits of financial statements for periods ending on or after December 15, 2016. Hence the earliest cohort to comply would be those having a 31 December year end. ISA 701 is also applicable only for listed companies (Para 5). Therefore only audit reports of listed companies were used. Bursa Malaysia mandates that audited financial statements must be submitted within four months after year end. For this purpose we examined the date of the auditor's report for evidence of timeliness or delay in view of the additional requirement to select and justify reporting KAM disclosure to those charged with governance of the entity.

We examined the number of KAMs reported to identify its nature and justification by auditors as to why among all the material items in the audit the KAMs disclosed were considered as the most significant. We also interviewed a few auditors of the Big 4 regarding the problems faced in wording and communicating KAMs as there is no standard boiler plate format to follow. We ranked the KAM reported in terms of most reported KAM and we analysed whether the KAM disclosed had possible association with industry type. We used descriptive statics and apply a grounded theory approach to identify possible emerging issues form the KAMs disclosed.

\section{Results and Discussions}

Table 1 below summarises the KAMs reported by 15 listed companies:

Table 1: Summary of KAMs Disclosures by Early 2017 Cohort

\begin{tabular}{|c|c|c|c|c|}
\hline NO & COMPANY & $\begin{array}{c}\text { AUDIT } \\
\text { OPINION }\end{array}$ & $\begin{array}{l}\text { AUDITOR } \\
\text { AND AU- } \\
\text { DIT RE- } \\
\text { PORT } \\
\text { DATE }\end{array}$ & $\begin{array}{l}\text { NUMBER OF } \\
\text { KAMS }\end{array}$ \\
\hline 1 & Maxwell & Disclaimer & $\begin{array}{l}\text { Baker Tilly } \\
28.4 .17\end{array}$ & $\begin{array}{l}\text { NIL-No KAM to be } \\
\text { reported if a disclaimer } \\
\text { audit report is issued. } \\
\text { Compliance with ISA } \\
701\end{array}$ \\
\hline 2 & Genting & Unqualified & PWC 4.4.17 & $\begin{array}{l}\text { Impairments of intan- } \\
\text { gibles, property plant } \\
\text { and equipment, in- } \\
\text { vestment (3) }\end{array}$ \\
\hline 3 & $\begin{array}{l}\text { Cycle and } \\
\text { Carriage }\end{array}$ & Unqualified & \begin{tabular}{|l|} 
PWC \\
22.2 .17 \\
\end{tabular} & $\begin{array}{l}\text { Inventory write down } \\
\text { (1) }\end{array}$ \\
\hline 4 & Nestle & Unqualified & \begin{tabular}{|l|} 
PWC \\
28.2 .2017 \\
\end{tabular} & $\begin{array}{l}\text { Revenue recognition } \\
\text { (1) }\end{array}$ \\
\hline 5 & CCM & Unqualified & $\begin{array}{l}\text { KPMG } \\
24.3 .17\end{array}$ & $\begin{array}{l}\text { Goodwill impairment, } \\
\text { inventory obsoles- } \\
\text { cence }(2)\end{array}$ \\
\hline 6 & Prestariang & Unqualified & \begin{tabular}{|l|} 
Crowe \\
Howarth \\
28.3.17 \\
\end{tabular} & $\begin{array}{l}\text { Recoverability of } \\
\text { development costs, } \\
\text { contract customers (2) }\end{array}$ \\
\hline 7 & Lafarge & Unqualified & $\begin{array}{l}\text { Delloitte } \\
28.3 .17\end{array}$ & $\begin{array}{l}\text { Goodwill impairment, } \\
\text { inventory obsoles- } \\
\text { cence }(2)\end{array}$ \\
\hline 8 & $7-11$ & Unqualified & EY & $\begin{array}{l}\text { Revenue recognition } \\
\text { (1) }\end{array}$ \\
\hline 9 & $\begin{array}{l}\text { Metronic } \\
\text { Global }\end{array}$ & Unqualified & $\begin{array}{l}\text { Siew Boon } \\
\text { Yeong Asso- } \\
\text { ciates }\end{array}$ & $\begin{array}{l}\text { Freehold land and } \\
\text { buildings, financial } \\
\text { assets, deferred tax } \\
\text { assets, trade receiva- } \\
\text { bles, revenue from } \\
\text { contract works (5) }\end{array}$ \\
\hline 10 & Cocoa Land & Unqualified & $\begin{array}{l}\text { UHY } \\
3.4 .2017 \\
\end{array}$ & $\begin{array}{l}\text { Inventory valuation, } \\
(2)\end{array}$ \\
\hline 11 & Air Asia & Unqualified & PWC 5.4.17 & $\begin{array}{l}\text { Revenue recognition, } \\
\text { impairment of invest- }\end{array}$ \\
\hline
\end{tabular}




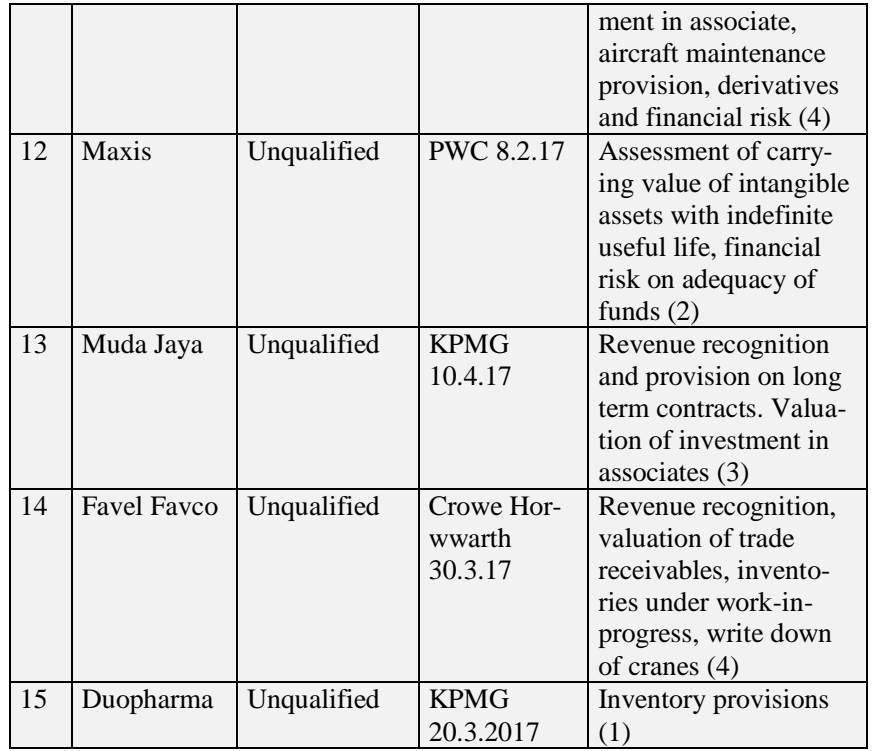

From Table 1 above, all audit reports evidenced compliance with the new audit regulation of ISA 710. Only one company received a disclaimer report and accordingly, following the requirement of ISA 710, that no KAM should be mentioned as disclaimers makes KAM irrelevant. The 14 unqualified audit reports give reasonable assurance that the financial statements audited were free from material misstatements. The KAM paragraphs of the 14 companies showed the number of KAMS deemed as significant or critical matters by the auditors. ISA 701 does not specify how many KAMS must be reported as a minimum and the maximum but leaves it to the judgement of the auditors. However Paragraph 30 of ISA 701 states that lengthy lists of KAM may be "contrary to the notion of such matters being those of most significance in the audit". Table 1 shows KAMs reported ranged from 1 to 5 matters which all relate to significant accounting policies disclosed in the notes to accounts. In studies on audit regulation Institutional Theory finds that when the regulator of the auditing profession (in Malaysia it would be MIA) in a particular country issues new directives, members of the profession would comply and change their behavior described as coercive isomorphism. Compliance is $100 \%$ because the directives come from a regulator empowered to sanction any non- compliance.

What were the KAMs reported? The highest number of KAM reported is revenue recognition and inventory valuation (10), followed by impairment of intangible assets, investments and trade receivables. This pattern is similar to KAMs disclosed in UK audit reports summarized by MAZARS (12) whereby most reported KAMs by 100 FTSE100 companies in UK 2014/15 audit reports were revenue recognition and asset impairment regardless of sector or industry. All audit reports were timely with no delay despite the additional costs involved in identifying, assessing and discussing KAM with those in charge of governance.

The audit report is addressed to shareholders specifically but ISA 710 identifies the users of the audit reports as "intended users" suggesting a wider audience. The conceptual framework for Malaysian Financial Reporting Standards as issued by the Malaysian Accounting Standards Board (MASB) identifies users of financial statements as investors, creditors and lenders. Whilst in form all the audit reports examined complied with a new paragraph disclosing KAMs, the rationale for selecting the number of items and which items merit being that which mattered most posed a greater challenge as it has to be couched specific to the current year situation and not a repeat of what has already been disclosed elsewhere in the financial statements. Discussions with a few audit staff of two Big 4 audit firms reveal that communicating highly technical matters in English was more challenging than selecting KAMs themselves. This difficulty is further compounded by the absence of a prototype report disclosure or template to help auditors explain why such an issue is a reportable KAM.

\section{Conclusion}

This paper reports on how auditors of Malaysian listed companies respond to the requirements of ISA701, a new auditing standard effective for financial statements audit for year ending on or after 15 December 2016. The standard ushered a new audit reporting regime as it mandates auditors to disclose, for the first time, information hitherto privy only to auditors and their clients, in the audit report itself. It therefore created a new reporting regime for Malaysian external auditors. Such items are deemed as most significant in the audit when reporting to those in charge of governance of the companies concerned. All 15 audit reports complied with the disclosure requirements appropriately. Based on 15 early audit reports available before 30 April 2017, our paper reports that none of the audit reports were delayed despite the need for greater disclosure in the audit report and no KAM boiler plate template is available to craft matters deemed as critical. Our study shows the number of KAMs reported ranged from one to five. The most cited KAMs are revenue recognition unique to the nature of clients' business and inventory valuation followed by valuation of intangibles. The new auditing standard has indeed forced auditors to communicate non-standard KAM. Auditors interviewed commented that the most challenging part of the new requirement is the selection of what constituted "most significant" and how to articulate it to ensure professionalism in communication. This paper contributes to a new research opportunity on the changing audit reporting regime in Malaysia as to date no paper has been published on the implications of KAM disclosure. Future research should consider whether KAM disclosure has enhanced audit quality and useful to intended users of audited financial statements or not.

\section{References}

[1] Kelly CF, Yong E, Gibson R. Auditor's perception of the audit process. Geelong, Vic: Deakin University. School of Management \& Accounting Association of Australia and New Zealand. Conference Melbourne, Vic.; 1990.

[2] ISA 701. Communication of Key Audit Matters in the Independent Auditor's Report. Malaysian Institute of Accountants;

[3] Bealing JWE, Dirsmith MW, Fogarty T. Early regulatory actions by the sec: An institutional theory perspective on the dramaturgy of political exchanges. Accounting, Organ Soc. 1996;21(4):317-38.

[4] Baker CR, Bédard J, Prat dit Hauret C. The regulation of statutory auditing: an institutional theory approach. Manag Audit J. 2014 May;29(5):371-94.

[5] Cordos G, Fülöp M. Understanding audit reporting changes: introduction of Key Audit Matters. Account Manag Inf Syst. 2015;14(1):128-52.

[6] Christensen BE, Glover SM, Wolfe CJ. Do Critical Audit Matter Paragraphs in the Audit Report Change Nonprofessional Investors' Decision to Invest? Audit A J Pract Theory. American Accounting Association; 2014 Apr;33(4):71-93.

[7] Bédard J, Gonthier-Besacier N, Schatt A. Costs and Benefits of Reporting Key Audit Matters in the Audit Report: The French Experience. 2014.

[8] Lennox C, Schmidt J, Thompson A. Does an expanded model of audit reporting improve the information environment for investors? Evidence from the UK. 2017.

[9] Reid LC, Carcello J V., Li C, Neal TL. Impact of Auditor and Audit Committee Report Changes on Audit Quality and Costs: Evidence from the United Kingdom. 2015.

[10] Sirois L-P, Bédard J, Bera P. The Informational Value of Key Audit Matters in the Auditor's Report: Evidence from an Eye-tracking Study. Account Horizons. American Accounting Association; 2018 Feb;

[11] Kachelmeier SJ, Schmidt JJ, Valentine K. The Disclaimer Effect of Disclosing Critical Audit Matters in the Auditor's Report. 2014.

[12] MAZARS. MAZARS Benchmark on key audit matters-New Auditor's Audit Report under ISA. 2016. 